\title{
EA Preliminary Study on Domestication of Bluespotted Snakehead (Channa Lucius, Channidae) in Concrete Tank
}

\section{Azrita $^{1 *}$, Yuneidi Basri ${ }^{2}$ and Hafrijal Syandri ${ }^{2}$}

${ }^{1}$ Department of Biology Education, Faculty of Education of Bung Hatta University Padang, Indonesia

${ }^{2}$ Department of Aquaculture, Faculty of Fisheries and Marine Sciences of Bung Hatta University Padang, Indonesia

\begin{abstract}
This study aim to gain insight into the domestication of Channa lucius female kept in a concrete tank as much as four plots of each size $200 \times 200 \times 75 \mathrm{~cm}$. C. lucius each concrete tank maintained by four females with an average weight of $300 \pm 20 \mathrm{~g} /$ individual and four males with an average weight of $500 \pm 50 \mathrm{~g} /$ individual. Treatment in this experiment consisted of four groups are control group (injection $0.9 \mathrm{NaCl}$ ) and exposed to $100 \mu \mathrm{g} / \mathrm{kg}$ body weight, $150 \mu \mathrm{g} / \mathrm{kg}$ body weight and $200 \mu \mathrm{g} / \mathrm{kg}$ body weight of LHRHa hormone preparations. Dose level best to increase the reproductive potential of $C$. lucius was $200 \mu \mathrm{g} / \mathrm{kg}$ body weight with time reaching a matured gonads $62 \pm 12$ days, fecundity was $2,617 \pm 250$ eggs/spaw, egg diameter $1.87 \pm 0.02 \mathrm{~mm}$, the survival embryo $85.92 \pm 0.52 \%$ and hatching rate $82.41 \pm 0.60 \%$. Dose level of LHRHa was significantly $(p<0.05)$ with time mature gonadal, fecundity and eggs diameter. Whereas hatching rate and embryo survival not significantly $(p>0.05)$ between treatments, but significantly $(p<0.05)$ different from the control group.
\end{abstract}

Keywords: Domestication; Channa Lucius; Lhrha; Matured gonadal; Fecundity; Egg diameter; Survival embryo; Hatching rate

\section{Introduction}

Channa lucius is a family Channidae includes air breathing freshwater fishes, popularly known as snakeheads or murrels. This species has an important economic value at a high price in the local market ranged between 40.000 to $50.000 \mathrm{IDR} / \mathrm{kg}$ [1], These are economically important species having great potential for aquaculture and capture fisheries in Indonesia, especially in the province of West Sumatra, Riau, Jambi and South Sumatra [2,3]. In addition to economically valuable genera of Channa also has important value for human health [4-9]. Zuraini et al. [4] stated meat proximate composition of C. lucius is crude protein 19.9\% (\% DW), crude fat $11.9 \%$, crude ash $1.2 \%$ and moisture $80.0 \%$ (\% WW). This fish is one of the genus Channa are an important source of protein for people throughout the Asia Pacific region [10].

This fish has a chance to do domestication cause basic data on the biology and ecology in nature are known ie are carnivores eating fish, shrimp and frogs, male fish size larger than females. Maturation of female broodstock on the size of the standard length ranged from 245.0 to $400.0 \mathrm{~mm}$ and body weight between 156.0 to $560.0 \mathrm{~g}$, total fecundity ranged from 1,152 to 3,746 grains/individual, egg diameter ranged between 1.35 to $1.70 \mathrm{~mm}$. While the maturation of male broodstock on the size of the standard length ranged from 260.0 to $485.0 \mathrm{~mm}$ and body weight between 112.50 to $656.0 \mathrm{~g}$ [11]. In natural spawning of $C$. lucius putting the eggs around the water plants floating on the surface of the waters [2]. The size of egg C. lucius approached the size of the eggs C. argus ranged from 1.80 to1.85 mm (Soin, 1960) in [12], the size of egg C. blehari ranges from 0.9 to $1.1 \mathrm{~mm}$ [12], and size of egg C. gachua ranges from 2.1 to $2.6 \mathrm{~mm}$ [13]. Fecundity of Chevron snakehead (C. striata) in Malaysia ranges from 3,000 to 30,000 grains, egg diameter $1.25 \mathrm{~mm}$ [14] and fecundity of Chevron snakehead (C. striata) in the floodplain Musi River of South Sumatra Province Indonesia range from 1,141 to 16,468 grains [15]. Domestication of the family Channidae among other C. punctatus induced with Ovatide been successfully performed [16] and C. striatus with HCG [17]. Based on using LHRHa hormone implantation method was important to gonadal maturation of $C$. lucius.

\section{Material and Methods}

\section{Broodstock}

The broodstock of C. lucius females and males as much as 100 individuals (Figure 1) were collected from fishermen in Rangau River Bengkalis Regancy, Riau Province. Fish samples were transported to Laboratory of Freshwater Fisheries Development Faculty of Fisheries and Marine Sciences of Bung Hatta University Padang, using a plastic bag filled with oxygen with a stocking densities 4 individuals/10 liters of water. Transport equipment used is the car with the distance of five hours $( \pm 200 \mathrm{~km})$ of fish sampling sites. In the laboratory all the fish adapted for three months in the concrete tank size of $6.0 \times 2.0 \times 0.75 \mathrm{~m}$

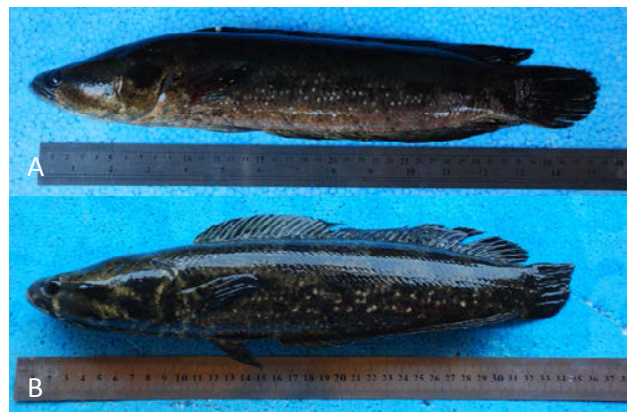

Figure 1: Female of C. lucius (A) Male of C. lucius (B)

*Corresponding author: Azrita, Department of Biology Education, Faculty of Education of Bung Hatta University Padang, Indonesia, Tel: 628126734212; E-mail: azrita31@yahoo.com

Received September 25, 2014; Accepted December 19, 2014; Published January 22, 2015

Citation: Azrita, Basri Y, Syandri H (2015) A Preliminary Study on Domestication of Bluespotted Snakehead (Channa Lucius, Channidae) in Concrete Tank. J Aquac Res Development 6: 309. doi:10.4172/2155-9546.1000309

Copyright: (c) 2015 Azrita, et al. This is an open-access article distributed under the terms of the Creative Commons Attribution License, which permits unrestricted use, distribution, and reproduction in any medium, provided the original author and source are credited. 


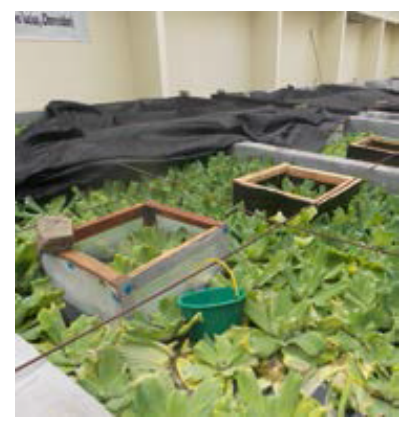

Figure 2: Maintenance concrete tank and spawning box.

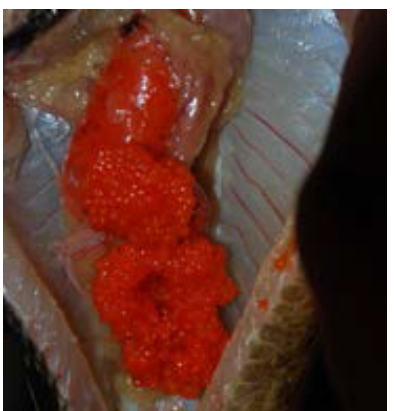

Figure 3: Spawning fish eggs of C. lucius stage IV.

with circulating water, volume of 6000 liters of water and fed of tilapia (Orechromis nilaticus) size 4 to $5 \mathrm{~cm}$ in adlibitum.

After three months maintained, female fish were selected as much as 16 tails with an average weight of $300 \pm 20$ grams which will be used for the four treatments and four replications with implantation of LHRHa hormone. C. lucius given treatment LHRHa with different doses twelve individuals and four individuals as a control $(0.9 \%$ $\mathrm{NaCl}$ ). All the fish are at stage 1 germinal vesicle in central position and distributed into four plots concrete tank size of $200 \times 200 \times 75 \mathrm{~cm}$, the water height of $50 \mathrm{~cm}$ and in the each concrete tank maintenance supplied wooden boxes size of $60 \times 40 \times 40 \mathrm{~cm}$ two units are equipped with water plants functioning as a spawning naturally (Figure 2 ). The number of female fish every concrete tank is four individuals added with two male fish weighing $500 \pm 50 \mathrm{~g} /$ individual. The concrete tank water comes from an artesian well to debit $0.1 \mathrm{~m}^{3} /$ second, concrete tank temperature ranged from 26 to $28^{\circ} \mathrm{C}, \mathrm{pH} 6.0$ to 7.0 , dissolved oxygen $(\mathrm{mg} / \mathrm{l})$ adalah 5,5 to 6,0 . The food is given once each day of tilapia (Orechromis nilaticus) size 4 to $5 \mathrm{~cm}$ (10 g/individual) as many as $15 \%$ of the weight of biomass or equivalent to 33 individual/day/plot.

\section{Checking the oocytes maturation}

All fish were individually marked using floy-tags and weighed. Oocytes sampled in vivo were taken from females using the method described by Syandri [18], and were placed in Serra's solution (6:3:1, $70 \%$ ethanol, $40 \%$ formaldehyde and $99.5 \%$ acetic acid). for clarification of the cytoplasm. After $5 \mathrm{~min}$, the position of oocytes nucleus was determined using a four-stage scale:

Stage 1 germinal vesicle in central position

Stage 2 early migration of germinal vesicle (less than half of radius)

Stage 3 late migration of germinal vesicle (more than half of radius)
Stage 4 periphery germinal vesicle or germinal vesicle breakdown, GVBD (Figure 3).

\section{Hormonal treatment}

Preparation of hormone pellets following the procedure as suggested by Lee et al. [19] is 1000 ug LHRHa hormone mixing with $70 \mathrm{mg}$ cholesterol, $20 \mathrm{mg}$ of cocoa butter (unsalted butter), $1 \mathrm{ml}$ etanol $70 \%$. The dough molded into pellets much as twenty grains and each pellet contains $50 \mu \mathrm{g}$ of LHRHa. Experiments conducted on C.lucius female gonad maturity stage one with four groups and four replications. Control group (injection from $0.9 \% \mathrm{NaCl}$ ) and three experimental ones. Group two, three and four given a single dose LHRHa with $100 \mu \mathrm{g} / \mathrm{kg}, 150 \mu \mathrm{g} / \mathrm{kg}, 200 \mu \mathrm{g} / \mathrm{kg}$ body weight. LHRHa intra muscular implanted under the dorsal fin. Spawning conducted are naturally, without stimulation hormone. Egg samples from each treatment and replications. Gilson is preserved with a solution consisting of $100 \mathrm{ml}$, $60 \%$ alcohol, $880 \mathrm{ml}$ of distilled water, $15 \mathrm{ml}$ of nitric acid, $18 \mathrm{ml}$ of glacial acetic acid and 20 grams of mercury chloride. Furthermore, the diameter of the eggs was measured with a microscope Olympus CX21 to 30 eggs of from each treatment and replications. Fertilized eggs were collected after ten hours and checked under a stereomicroscope. The

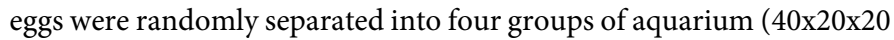
$\mathrm{cm}$, water volume 8 liter), with four replicates for the control and four replicates for each exposure group. The total number of eggs in the control and the exposure groups was 100 eggs. The water temperature, dissolved oxygen, and $\mathrm{pH}$ levels of the test chambers were regularly monitored.

Time mature gonadal calculated from the time the fish began to LHRHa granted until the fish reaches a mature gonadal (days). Fecundity is the number of eggs produced per spawning, embryo survival (\%) is the number of fertilized eggs compared to the number of eggs produced per spawning and $s$ the hatching rate is number of larval compared to the number of fertilized eggs.

\section{Statistical analyses}

All data were analysed by analysis of variance (ANOVA), followed by comparisons of means by Duncan's multiple range test. In the case of time of mature gonadal, total fecundity, egg diameter, embryo survival and hatching rate. The mean of the duplicate samples was used for each fish. All statistical analyses were performed using the SPSS versi 13 .

\section{Results}

The mean time to reach the gonadal mature of the control group was 122 days, whereas in LHRHa treatment group on average ranged from 92 to 112 days (Table 1). There were significant differences $(p<0.05)$ between treatment groups LHRHa against time reaches mature gonadal. Irrespectively of applied hormonal dose (also in the control group) all females of the domestic stock ovulated.

The fast average time it reaches the gonadal mature female broodstok is $92 \pm 12$ days for $200 \mu \mathrm{g} / \mathrm{kg}$ body weight, whereas later in the control group is $122 \pm 23$ days. There is an indication of the higherdose LHRHa, reached gonadal mature of C.lucius will be faster. There are significant differences between treatment groups to time reaches gonadal mature of C.lucius $(\mathrm{p}<0.05)$. Broodstock natural spawning $100 \%$ for each group in the treatment of LHRHa include control group.

The average number of eggs C.lucius from the natural spawning by LHRHa dose treatment and control are listed in Table 1. The number 
Citation: Azrita, Basri Y, Syandri H (2015) A Preliminary Study on Domestication of Bluespotted Snakehead (Channa Lucius, Channidae) in Concrete Tank. J Aquac Res Development 6: 309. doi:10.4172/2155-9546.1000309

Page 3 of 5

\begin{tabular}{|c|c|c|c|c|}
\hline \multirow[b]{2}{*}{ Parameter } & \multicolumn{4}{|c|}{ Dose hormone LHRHa } \\
\hline & $\begin{array}{c}\text { Group 1- } \\
\text { control }(0.9 \% \mathrm{NaCl})\end{array}$ & $\begin{array}{c}\text { Group 2- } \\
100 \mu \mathrm{g} / \mathrm{kg} \text { body weight }\end{array}$ & $\begin{array}{c}\text { Group 3- } \\
150 \mu \mathrm{g} / \mathrm{kg} \text { body weight }\end{array}$ & $\begin{array}{c}\text { Group 4- } \\
200 \mu \mathrm{g} / \mathrm{kg} \text { body weight }\end{array}$ \\
\hline Avarage weight of female (g) & $300 \pm 25$ & $300 \pm 20$ & $300 \pm 28$ & $300 \pm 30$ \\
\hline Time mature gonadal (days) & $122 \pm 23^{\text {aw }}$ & $112 \pm 15^{b}$ & $110 \pm 20^{c}$ & $92 \pm 12^{d}$ \\
\hline Percentace of natural spaw (\%) & $100^{\mathrm{a}}$ & $100^{\mathrm{a}}$ & $100^{\mathrm{a}}$ & $100^{\mathrm{a}}$ \\
\hline Fecundity (eggs/spaw) & $1,778 \pm 20^{a}$ & $2,106 \pm 200^{b}$ & $2,685 \pm 165^{c}$ & $3,600 \pm 152^{d}$ \\
\hline Egg diameter (mm) & $1.33 \pm 0.05^{\mathrm{a}}$ & $1.77 \pm 0.02^{b}$ & $1.81 \pm 0.01^{c}$ & $1.88 \pm 0.01^{\mathrm{d}}$ \\
\hline Embryo survival (\%) & $64.00 \pm 3.77^{a}$ & $83.03 \pm 0.51^{\mathrm{b}}$ & $83.56 \pm 0.14^{b}$ & $85.87 \pm 0.16^{b}$ \\
\hline Hatching rate $(\%)$ & $64.01 \pm 3.35^{\mathrm{a}}$ & $80.56 \pm 0.38^{b}$ & $80.96 \pm 0.63^{b}$ & $82.67 \pm 0.30^{\mathrm{b}}$ \\
\hline Survival rate of larvae 6 days (\%) & $100^{\mathrm{a}}$ & $100^{\mathrm{a}}$ & $100^{\mathrm{a}}$ & $100^{\mathrm{a}}$ \\
\hline
\end{tabular}

${ }^{\text {abcd }}$ Values with the different superscript in each column are significantly different from each other $(p<0.05)$

Table 1: Average reproductive potential and quality of eggs $C$. lucius.

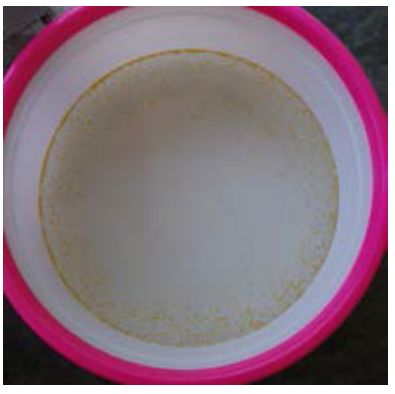

Figure 4: Embryo of $C$. lucius.

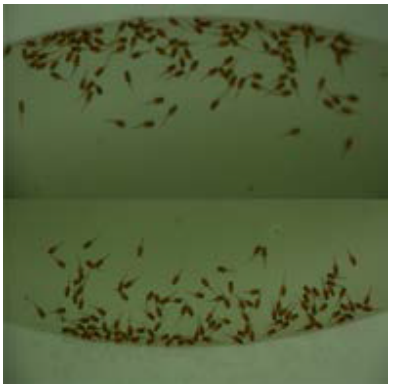

Figure 5: Larvae of C. lucius.

of eggs per spawning tendency to increase with increasing dose levels LHRHa. Average fecundity in the control group and the group that implanted with LHRHa preparations was significantly different ( $\mathrm{p}$ $<0.05)$. But every C. lucius broodstock that spawn at a dose level of LHRHa of $200 \mu \mathrm{g} / \mathrm{kg}$ body weight resulted in more number of eggs than the control group and at dose levels of $100 \mu \mathrm{g} / \mathrm{kg}$ and $150 \mu \mathrm{g} / \mathrm{kg}$ body weight.

The average egg diameter of C.lucius for each treatment dose of LHRHa hormone preparations and the control group was significantly different $(p<0.05)$. The diameter of the largest egg of $1.87 \pm 0.02 \mathrm{~mm}$ produced by C.lucius implanted LHRHa hormone preparations of dose level $200 \mu \mathrm{g} / \mathrm{kg}$ body weight and smallest size $1.33 \pm 0.05 \mathrm{~mm}$ produced by the control group. The size of the diameter of the eggs was significantly different between treatments $(p<0.05)$. Furthermore, the colour of egg C.lucius is dark orange (Figure 3), embryo is floating and do not stick to each other in the hatching medium (Figure 4). During the process of embryonic development not given the addition of oxygen and embryonic development to hatching at $28^{\circ} \mathrm{C}$ water temperature ranged from 30 to 36 hours. Embryo survival between treatment groups were not significantly different $(\mathrm{p}>0.05)$, but significantly different from the control group $(\mathrm{p}<0.05)$. Average embryo survival in the treatment group LHRHa ranged between $83.03 \pm 0.51 \%$ to $85.87 \pm$ $0.16 \%$ and the highest embryo survival produced by female broodstock LHRHa preparations were implanted with a dose of $200 \mu \mathrm{g} / \mathrm{kg}$ body weight and $64.00 \pm 3.77 \%$ lowest in the control group and maintained in the same environment with indicators of water quality parameters is important that is water temperatures ranged from 24 to $27^{\circ} \mathrm{C}, \mathrm{pH}$ ranged from 6.5 to 7.0 and dissolved oxygen ranged from 6 to $7 \mathrm{mg} / \mathrm{l}$.

Average hatching rate in the control group are $64.01 \pm 3.35 \%$, whereas in the group treated preparations LHRHa ranged between $80.56 \pm 0.38 \%$ to $82.67 \pm 0.30 \%$. Hatching rate between LHRHa treatment group was not significantly different $(\mathrm{P}>0.05)$, and different from the control group $(\mathrm{p}<0.05)$. Egg yolk and oil bubble is a food reserve (first) after hatching the larvae of $C$. lucius. Absorbed yolk out for 92 hours ( 4 to 5 days) after hatching and for each treatment group and the control group survival rate of larvae on average 100\% (Figure 4). C.lucius larvae at the beginning of exogenous feeding can directly take Moina sp, although in this research author has not been able to determine large mouth aperture larvae. Therefore, continued research on larval rearing is very important (Figure 5).

\section{Discussion}

Gonadal maturation process of C. lucius for increasing the reproductive potential and the best quality eggs needed LHRHa dose of $200 \mu \mathrm{g} / \mathrm{kg}$ body weight. Implantation of LHRH-a physiologically can release of GTH with slowly. Gonadotropin hormone will stimulate the development of granulosa cells and after reaching a certain development granulosa cells to release estradiol. Estradiol stimulates the liver to form the vitellogenin that will stimulate the vitelogenesis in ovaries. After reaching a certain cell targets, vitellogenesis process ended, the granulosa cells will secrete steroid hormones stimulating gonadal maturation. The optimal dose for accelerate the gonadal mature of each species of fish is different, Balanthiocheilus melanopterus Cyprinidae fish needed LHRHa $25 \mu \mathrm{g} / \mathrm{kg}$ body weight [20], C. pleurothalmus needed $150 \mu \mathrm{g} / \mathrm{kg}$ body weight [21], Mystus nemurus Bagridae $100 \mu \mathrm{g} /$ $\mathrm{kg}$ body weight [22], Epinephelus fuscoguttatus Serranidae $150 \mu \mathrm{g} / \mathrm{kg}$ body weight [23]. Differences LHRHa dose every type of fish allegedly due to differences in fish species, thus providing different responses for each type of fish reaches a gonadal mature.

LHRHa dose effects on fecundity has been studied by some researchers but there are inconsistencies in the reported results. Fecundity produced by Botia macracantha with LHRHa dose of 150 $\mu \mathrm{g} / \mathrm{kg}$ body weight a average of $19.615 \mathrm{eggs} / \mathrm{spawning}$, whereas at a dose of $200 \mu \mathrm{g} / \mathrm{kg}$ body weight fecundity as much as 10,203 eggs/spawning 
[24]. In this study with increasing doses of LHRHa hormone, then the increasing fecundity every spawning. Fecundity of C.lucius highest average of 3,600 \pm 152 eggs / individuals, whereas the control group $1,778 \pm 20$ eggs/ individuals. Differences fecundity of each treatment group LHRH is suspected related with a dose of the hormone LHRHa in implantation. Whereas LHRH-a alone function to promote secretion of gonadotropin (GTH) from the pituitary gland, given fixed with a certain dose to ensure certainty of oocyte maturation. The success of the effect of the hormone on gonad development should be supported the maintenance of environmental conditions and adequate feeding [21]. C. lucius during maintained in the process of maturing the gonads were fed live ie tilapia juvenile (Oreochromis nilaticus).

The feed can sustain the life of $C$. lucius and assist in the maturation of the gonads because it allegedly contains compounds of fatty acids. Mokoginta [25] states that there is a tendency broodstock who gets feed to the linoleic fatty acid content of less or more will produce a low fecundity. The growth of the embryo very dependent on the quality and quantity of nutrients stored in the yolk, because the egg membranes are impermeable amino acids and nucleotides (Neyfaakh and Abromova, 1974) in [25]. Ontogenesis of success generated by the conversion of yolk material into embryonic tissues [18].

Increasing the diameter of the eggs C. lucius from $1.33 \mathrm{~mm}$ to 1.88 $\mathrm{mm}$ caused by the implantation of LHRHa hormone because it was bigger than the diameter of the eggs in the control group. According Subagja et al. [24] Botia fish (Botia macrachanta) eggs treated with LHRH-a can grow from the size of $0.35 \mathrm{~mm}$ to $0.80 \mathrm{~mm}$ and ready ovulated, while the parent is not given LHRH the godanal undeveloped. Grouper eggs which have diameters ranged from 60 to $380 \mu \mathrm{m}$ required optimal dose of $100 \mathrm{ug}$ LHRHa/kg body weight [26]. From the research it can be stated that egg size $C$. lucius relatively large and large eggs will larvae tend to have a large mouth openings making it easier to accept as natural food such as Artemia salina nauplii when the change of food from endogenous feeding to exogenous feeding. Therefore C. lucius can be recommended for performed as a candidate culture of farmed fish. This opinion refers to the results of research Syandri [27] to Tor douronensis, the size of the newly hatched larvae are $1.1 \mathrm{~mm}$ and at the age of four days can directly take Artemia salina nauplii as a natural feed so that larvae survival can reach $80 \%$. Different from the larvae newly hatched Mystacoleucus padangensis Blkr have a size of 0.2 to 0.3 $\mathrm{mm}$, very difficult to provide natural food and at the age of 13 days to take of Artemia salina nauplii, consequently larval survival to the age of 14 days only $10 \%$ [18]. During embryonic development and hatching eggs several water quality parameters monitored are as follows water temperature ranged from 27 to $29^{\circ} \mathrm{C}, \mathrm{pH}$ ranged from 6.5 to 7.0 and dissolved oxygen ranged from 6 to $7 \mathrm{mg} / \mathrm{l}$ and ammonia $0.02 \mathrm{mg} / \mathrm{l}$. According Boyd [28] good fish growth occurs at temperatures 25 to $32^{\circ} \mathrm{C}$, pH 6.5 to 9.0 and dissolved oxygen $>5 \mathrm{ppm}$.

\section{Conclusion}

Increasing doses of the hormone LHRH-a at broodstock females in general can increase the time mature gonadal, fecundity, eggs diameter, embryo survival and hatching rate. The best dose is $200 \mu \mathrm{g} / \mathrm{kg}$ body weight.

\section{Acknowledgements}

We are indebted to The Ministry of Education and Culture Directorate General of Higher Education to providing research funding Competitive Grants 2014 and Faculty of Fisheries and Marine Sciences of Bung Hatta University Padang for providing full laboratory facilities during the study period. There is no conflict of interest among the authors for the publication of this research article, and also thank to reviewers at JARD for valuable criticism of the manuscript.

\section{References}

1. Azrita (2011) Patterns of growth and condition factor of Channa lucius in Singkarak Lake.

2. Azrita, Syandri H (2013) Fecundity, egg diameter and food Channa lucius Cuvier in different waters habitats. J Fish Aqua Sci 4: 115-120.

3. Warsa A, Nastiti AS, Krismono, Nurfiarini A (2009) Fisheries resources in Koto Panjang Reservoir. Bawal 2: 93-97.

4. Zuraini A, Somchit MN, Solihah MH, Goh YM, Arifah AK, et al. (2006) Fatty acid and amino acid composition of three local Malaysian Channa spp. Fish. Food Chemistry $97: 674-678$.

5. Lu F, Ding Y, Ye X, Liu D (2010) Cinnamon and nisin in alginateecalcium coating maintain quality of fresh northern snakehead fish fillets. LWT- Food Science and Technology 43: 1331-1335.

6. Karapanagiotidis IT, Yakupitiyage A, Little D, Bell MV, Mente E (2010) The nutritional value of lipids in various tropical aquatic animals from rice-fish. $J$ Food Com Analy 23: 1-8.

7. Sood N, Chaudhary DK, Rathore G, Singh A, Lakra WS (2011) Monoclonal antibodies to snakehead, Channa striata immunoglobulins: Detection and quantification of immunoglobulin-positive cells in blood and lymphoid organs. Fish Shellfish Immunol 30: 569-575.

8. Ghassem M, Arihara K, Babji AS, Mamot S, Ibrahim S (2011) Purification and identification of ACE inhibitory peptides from Haruan (Channa striatus) myofibrillar protein hydrolysate using HPLC-ESI-TOF MS/MS. Food Chemistry 129:1770-1777.

9. Xu FL, Wu WJ, Wang JJ, Qin N, Wang Y, et al. (2011) Residual levels and health risk of polycyclic aromatic hydrocarbons in freshwater fishes from Lake Small Bai-Yang-Dian, Northern China. Ecological Modelling 222: 275-286.

10. Mohsin AK, Ambak MA (1983) Freshwater fishes of arginine supplementation enhances diabetic wound healing: peninsular malaysia. Serdang, Malaysia: Universiti Pertanian involvement of the nitric oxide synthase and arginase pathways.

11. Azrita (2012) Genetic variation and reproductive biology of Channa lucius Cuvier [Actinopterygii: Channidae] on different aquatic habitats in an effort to domestication.

12. Courtenay WR, Williams JD (2004) Snakeheads (Pisces, Channidae) A biological synopsis and risk assessment.

13. Mishra SK (1991) Reproductive biology of freshwater teleost, Channa gachua (Ham): Proceedings of the National Symposium on New Horizons in Freswater Aquaculture.

14. Jhingran AG (1984) The fish genetic resources of India: Bureau of Fish Genetic Resources, Allahabad and Maya Press Pvt. Ltd, Allahabad.

15. Makmur S, Rahardjo MF, Sukimin S (2003) Biology reproductive of Channa striata Bloch in floodplain Musi River South Sumatra. J Iktiologi Indonesia 3 : $57-62$.

16. Marimuthu K, Haniffa MA, Rahman MA (2009) Spawning performance of native threatened spotted snakehead fish, Channa punctatus (Actinopterygii: Channidae: Perciformes), Induced with ovatide. Acta Ichthyologica Et Piscatoria 39: 1-5

17. Paray BA, Haniffa MA, Manikandaraja D (2012) Induced ovulation and spawning of a striped snakehead murrel, Channa striatus (Bloch) under captive conditions. J Res Ani Sci 1: 033-039.

18. Syandri H (1997) Development of fish embryos and larvae bilih, Mystacoleucus padangensis Blkr in Singkarak lake. J Garing 2: 28-38.

19. Lee CS, Tamaru K, Kelly CD (1986) Technique for Making Chronic-release LHRHa and 17 methyltestosterone pelets for intramuscular implantation in fishes. Aquaculture 59: 161-168.

20. Insan I, Satyani D, Munddriyanto H, Kusdiarti, Djajasewaka H (2001) Dose differences hormone LHRH for the maturation of gonads Balasark (Balanteocheilus melanopterus). J Biosfera 18: 13-19.

21. Syandri H, Basri Y, Maseriza (2008) The Use of LHRH-a and Vitamine E for eggs quality of Channa pleurothalmus). Journal of Sigmatek 1: 131-144.

22. Aryani N, Syawal H, Bukhari D (2002) The use of LHRH-a for gonada 
Citation: Azrita, Basri Y, Syandri H (2015) A Preliminary Study on Domestication of Bluespotted Snakehead (Channa Lucius, Channidae) in Concrete Tank. J Aquac Res Development 6: 309. doi:10.4172/2155-9546.1000309

Page 5 of 5

maturation of green catfish (Mystus nemurus). Torani 12: 163-168.

23. Purba R (1995) Supporting Role of LHRHa for Tiger Grouper (Epinephelus fuscoguttatus) breeding, Research News 17: 7-8.

24. Subagja J, Komarudin O, Effendi J (1997) Effects of LHRH-a hormone implantation in Botia (Botia macrachanta) on gonadal maturation variability. $\mathrm{J}$ Indonesian Fisheries Research 2: 10-17.

25. Mokoginta I (2000) Needs essential fatty acids, vitamins and minerals in feed broodstock (Pangasius sutchi) for reproduction. The final report VII/1-2 Competitive Grant Universities.
26. Setiadharma T, Prijono A, Giri NA (2003) LHRH-a hormone application for gonadal development and spawning grouper (Epinephelus microdon). Journal of Indonesian Fisheries Research 1: 9-16.

27. Syandri $H$ (2004) The use of vitamin $E$ for enhancing the reproductive potential of Garing fish (Tor douronensis Blk). J Agricultural Dynamics XIX: 141-151.

28. Boyd CE (1979) Water quality in warmwater fish ponds. Agricultural Auburn University. Alabama. 